\title{
Peran Pengelolaan Dokumen Kepemilikan Aset Berbasis ISO 9001: 2015 Terhadap Upaya Revitalisasi Jalur Kereta Api di Indonesia
}

\author{
Rina Rakhmawati ${ }^{1 *}$ Ichwan $^{2}$; Elya Riska Dwi Wahyuni ${ }^{1}$ \\ ${ }^{1}$ Sekolah Vokasi, Universitas Gadjah Mada \\ ${ }^{2}$ Kantor Pusat PT Kereta Api Indonesia (Persero) \\ *Korespondensi: rinaarsip@ugm.ac.id
}

\begin{abstract}
This study aims to describe the management of railroad asset documents based on ISO 9001: 2015 regarding the Quality Assurance System in supporting the revitalization program of several railway lines in Indonesia. In the process of revitalizing the railroad tracks, documents are needed as the main reference. Asset documents used in the railroad revitalization activities are documents in the form of technical drawings, ownership assets documents, and cartography. The data used in this study are primary data, which were obtained from participatory observations in 2019, in-depth interviews, and review of document asset document management activities. Secondary data were obtained from literature reviews in the form of books, legislation, scientific articles, and literature extracted from internet sources. These data are processed by data triangulation analysis. The benefit of this research is to describe document management based ISO9001:2015 and to analyze the impact of the document management model on the revitalization program for Indonesian railroad tracks. The conclusion is that asset document management based on ISO 9001: 2015 has an important role in supporting the railroad revitalization program in Indonesia. This is because in revitalizing the railway line, a guideline is needed to reconstruct the structure of the railroad track when the line was still actively used. If the asset documents are in a damaged condition, both physical and informational, then the reconstruction process will require greater costs and longer time.
\end{abstract}

Keywords: managing; document; asset; separated; railway

\begin{abstract}
Abstrak
Penelitian ini bertujuan mendeskripsikan pengelolaan dokumen aset kereta api yang didasarkan pada ISO 9001: 2015 tentang Sistem Jaminan Mutu dalam mendukung program revitalisasi beberapa jalur kereta api di Indonesia. Dalam proses revitalisasi jalur kereta tentunya dibutuhkan dokumen sebagai acuan utama. Dokumen aset yang digunakan dalam kegiatan revitalisasi jalur kereta api adalah dokumen yang berupa gambar teknik, dokumen aset kepemilikan, dan kartografi. Data yang digunakan dalam penelitian ini berupa data primer, yang diperoleh dari observasi partisipasi pada tahun 2019, in-depth interview, dan pengkajian terhadap dokumen kegiatan pengelolaan dokumen aset. Data sekunder diperoleh dari kajian pustaka berupa buku, perundangundangan, artikel ilmiah, maupun literatur yang digali dari sumber internet. Data-data tersebut diolah dengan analisis triangulasi data. Manfaat dari penelitian ini yaitu untuk mendeskripsikan pengelolaan dokumen berbasis ISO, serta menganalisis dampak model pengelolaan dokumen tersebut terhadap program revitalisasi jalur kereta api di Indonesia. Adapun kesimpulan yang diperoleh yaitu pengelolaan dokumen aset dengan basis ISO 9001: 2015 memiliki peran penting mendukung program revitalisasi jalur kereta api di Indonesia. Hal ini disebabkan dalam merevitalisasi jalur kereta api dibutuhkan pedoman untuk merekonstruksi ulang struktur jalur kereta pada masa jalur tersebut masih aktif dipergunakan. Apabila dokumen aset dalam kondisi rusak, baik fisik maupun informasinya, maka proses rekonstruksi ulang akan membutuhkan biaya lebih besar dan waktu yang lebih lama.
\end{abstract}

Kata Kunci: pengelolaan; dokumen; aset; jalur kereta api

\section{PENDAHULUAN}

Kereta api merupakan salah satu moda transportasi angkutan darat yang kini banyak digemari oleh masyarakat Indonesia. Kereta api juga menjadi salah satu penanda zaman masuknya pengaruh revolusi industri yang terjadi di Eropa ke Indonesia. Keberadaan moda kereta api dimulai dengan pembangunan jalur rel kereta sejak masa kolonial Belanda lebih dari 150 tahun yang lalu. Tujuan utama pembangunan jalur rel kereta beserta pengadaan angkutan kereta adalah kemudahan dalam pengangkutan hasil bumi dari pedalaman menuju pelabuhan sehingga dapat diperdagangkan lintas negara. Selain itu, kereta juga digunakan sebagai sarana untuk keperluan perang mengangkut tentara dan mobilisasi peralatan perang. Pembangunan jalur kereta 
api, pada mulanya dilakukan melalui konsesi. Proposal konsesi kereta api pertama kali diajukan oleh pengusaha perkebunan yaitu W Poolman, A Fraser dan EH Kol kepada Pemerintah Hindia Belanda dengan jalur Semarang-Pecarongan-Gubuk-Purwodadi-Surakarta-Yogyakarta Pada tahun 1860 (Raap, 2018). Dua tahun setelah pengajuan tersebut, Gubernur Jendral Hindia Belanda LAJW Baron Sloet van den Beele menyetujui proposal Poolman dkk dengan perubahan jalur Semarang-Solo-Yogyakarta-Brosot ditambah jalur cabang Kedungjati-Ambarawa (Fort Willem I). Selanjutnya mereka pada tahun 1863 , mendirikan perusahaan kereta api pertama yang bernama Nederlandsch Indische Spoorweg Maatschappij (NISM). Jalur kereta api tersebut mulai dibangun tahun 1864 dan beroperasi tahun 1867 menghubungkan Stasiun Samarang ke Stasiun Tanggung sejauh 24,7 km. Selanjutnya pembangunan jalur dilanjutkan ke arah Solo sampai dengan Yogyakarta.

Dinamika sejarah perkeretaapian tersebut didokumentasikan dalam arsip yang dikelola oleh PT. Kereta Api Indonesia (Persero). Arsip, dalam konteks perusahaan, selain merujuk pada Undang-Undang Nomor 43 Tahun 2009 tentang Kearsipan, juga masih mengacu pada istilah dokumen perusahaan. Menurut Undang-Undang Nomor 8 Tahun 1997 tentang Dokumen Perusahaan, definisi dari dokumen perusahaan adalah data, catatan, dan atau keterangan yang dibuat dan atau diterima oleh perusahaan dalam rangka pelaksanaan kegiatannya, baik tertulis di atas kertas atau sarana lain maupun terekam dalam bentuk corak apapun yang dapat dilihat, dibaca, atau didengar. Dalam tulisan ini selanjutnya akan menggunakan dokumen dalam penyebutan arsip di perusahaan.

Keberadaan perusahaan kereta api di Indonesia sudah lebih dari 150 tahun yang lalu. Di mulai dari tahun 1864 dan terdiri dari banyak perusahaan kereta api baik milik pemerintah maupun swasta dengan lebih dari 20 perusahaan yang tersebar di Sumatera, Jawa, Madura dan Sulawesi. Pada masa itu pengelolaan dokumen pada perusahaan kereta api telah dilaksanakan dengan baik hal ini bisa dibuktikan dengan masih tersimpannya dokumen-dokumen tersebut khususnya perusahaan swasta di National Archives of The Netherlands (NAN) di Den Haag sampai saat ini. Hanya saja seiring dengan dinamika yang terjadi pada masa pendudukan Jepang, perang kemerdekaan, pergolakan politik 1965 dan perubahan beberapa kali status perusahaan menjadikan penyelenggaran dokumen sempat terabaikan sehingga dokumen sebagian rusak, hilang dan kurang dirawat sebagaimana mestinya. Turning point penyelenggaraan dokumen di PT Kereta Api Indonesia dimulai kembali pada tahun 2009 dengan dibentuknya Unit Corporate Document Management (USD) yang secara spesifik mengurusi semua dokumen perusahaan.

Seiring dengan transformasi bisnis dalam skala massif yang dilakukan, manajemen perusahaan merasa bahwa problem besar yang menghambat ekspansi bisnis berikut peningkatan pelayanannya saat itu banyak disebabkan oleh problem kepemilikan aset perusahaan yang ternyata berawal dari buruknya pengelolaan dokumen. Solusinya bisa dilakukan melalui pengelolaan dokumen yang baik agar dapat memutus backlog pengelolaan dokumen sekaligus membuka ruang untuk pengembangan kedepan agar bisa membawa pada daya saing perusahaan. Untuk itu dibuatlah roadmap penyelenggaraan dokumen sebagai panduan penyamaaan visi berikut langkah-langkah yang dilakukan, tentunya dengan sumber daya yang terbatas dan tuntutan kinerja yang yang tinggi diharapkan semuanya dapat meningkatkan ketersediaan dokumen yang diperlukan dalam bisnis (availability) dan selanjutnya secara bertahap yang dilakukan untuk memenuhi aspek kepatuhan pada peraturan (compliance), konsisten dalam pelayanan (consistency of services) dan selalu melakukan peningkatan kualitas (continualy improvement) tentunya menurut skala prioritas yang ditentukan.

Dokumen kepemilikan aset yang dikelola oleh USDA Kantor Pusat PT Kereta Api Indonesia (Persero) dikategorikan sebagai arsip vital. (Franks, 2018) menyebutkan konsep pengelolaan arsip vital terdiri dari planning a vital records program, vital records inventory, vital 
records analysis, dan vital records protection. Implementasi konsep pengelolaan arsip vital, salah satunya dilakukan oleh kantor notaris (Hayati, N.\&Noviani, 2019), dengan tahapan penggunaan arsip, pemeliharaan arsip, dan penyimpanan arsip. Model pengelolaan dokumen vital juga dianalisis dengan pendekatan kontinum dokumen yang menyimpulkan bahwa dokumen vital tidak dapat dimusnahkah (Novanti, D, \& Hermintoyo, 2019). Selain aspek teknis pengelolaan, dampak pengelolaan dokumen vital juga telah dikaji dari beberapa perspektif, seperti penilaian risiko (Vannia, 2019), kebutuhan informasi (Pamungkas, D.A\&Kurniawan, 2019), penyelamatan informasi (Qowam, P.A\&Permata, 2019), kebencanaan (Nurtanzila, 2018), dan pelestarian melalui digitalisasi (Elmawati\&Ismiyati, 2017). Makalah ini difokuskan pada pengelolaan dokumen kepemilikan aset kereta api yang berbasis pada ISO 9001: 2015 tentang Sistem Manajemen Mutu. Adapun manfaat yang diperoleh dari penerapan ISO 9001: 2015 tentang Sistem Manajemen Mutu adalah:

1. Kemampuan untuk menyediakan produk dan jasa secara konsisten yang memenuhi kebutuhan pelanggan dan persyaratan hukum serta peraturan yang berlaku;

2. Memfasilitasi peluang untuk meningkatkan kepuasan pelanggan;

3. Menangani risiko dan peluang yang terkait dengan konteks dan tujuannya;

4. Kemampuan untuk menunjukkan kesesuaian terhadap persyaratan sistem manajemen mutu yang ditentukan.

Mulyadi (2017) dalam kajiannya mendeskripsikan model pengelolaan dokumen transportasi dan prosedur layanan yang diberlakukan. Namun demikian, kajian tersebut belum menganalisis dan mendeskripsikan dampak pengelolaan dokumen terhadap upaya merevitalisasi jalur kereta api. Berdasarkan latar belakang permasalahan tersebut, maka pertanyaan penelitian yang diajukan dalam tulisan ini adalah:

1. Bagaimana model pengelolaan dokumen aset kereta api dengan basis ISO 9001: 2015 tentang Sistem Manajemen Mutu?

2. Bagaimana peran pengelolaan dokumen aset kereta api dalam program revitalisasi jalur kereta api di Indonesia?

\section{METODE PENELITIAN}

Tulisan ini didasarkan pada hasil penelitian yang bersifat kualitatif, yaitu mendeskripsikan analisis pengaruh program pelestarian dokumen jalur kereta api terhadap keberhasilan upaya revitalisasi jalur kereta api. Data yang digunakan terdiri dari data primer dan data sekunder (Moleong, 2014). Data primer dikumpulkan melalui observasi partisipasi dan wawancara tidak terstruktur. Wawancara tidak terstruktur melibatkan 2 narasumber dari pegawai Kantor Pusat PT Kereta Api Indonesia (Persero). Kedua narasumber tersebut dipilih berdasarkan penguasaan terhadap objek penelitian dan pengalaman kerja dalam menangani dokumen di Kantor Pusat PT Kereta Api Indonesia (Persero). Sedangkan data sekunder dilakukan dengan mengkaji berbagai bahan pustaka, baik berupa buku, jurnal, maupun produk hukum. Data tersebut kemudian dilakukan validasi dengan pendekatan triangulasi data. Data diperiksa keakuratan dan kredibilitasnya dengan cara menyelaraskan hasil observasi, wawancara, dan tinjauan pustaka. Langkah selanjutnya adalah mengorganisir data, kemudian memberi makna pada konteks data. Langkah terakhir adalah peneliti menginterpretasikan data yang telah diperoleh untuk menghasilkan kesimpulan yang valid (Moleong, 2014).

\section{HASIL DAN PEMBAHASAN}

Model pengelolaan dokumen di PT Kereta Api Indonesia (Persero) didasarkan pada konsep pengelolaan pada Unit Corporate Document Management (USD) yang dituangkan dalam suatu roadmap. Roadmap menjadi panduan dalam penyelenggaraan dokumen perusahaan yang terbagi 
dalam tiga tahap: Tahap I (2009-2015): Mobilisasi Sumberdaya, untuk mencapai standarisasi (standardization) penyelenggaraan dokumen perusahaan dan ketersediaan (availability) dokumen untuk pelayanan, Tahap II (2015-2020): Efektifitas-efisiensi pada proses dan delivery penyelenggaraan dokumen perusahaan, untuk mencapai kecukupan (adequation) dan kepatuhan (compliance) dalam pelayanan agar pengelolaan dokumen semakin beradaptasi dengan risiko (safety and security) dengan terus melakukan upaya perbaikan yang berkelanjutan (continualy improvement), Tahap III (2020 - ...): Document Integration System, untuk mencapai penyelenggaraan dokumen berkelas dunia (world class document management).

Kerangka model tersebut adalah Sistem Manajemen Mutu (SMM) ISO 9001:2008. Menurut narasumber 1 (wawancara tanggal 19 Juli 2019 di USDA Kantor Pusat PT Kereta Api Indonesia), melalui sistem tersebut penyelenggaraan dokumen perusahaan diarahkan pada kualitas hasil pengelolaan yang sistematis yang berorientasi pada pelayanan dokumen yang semakin baik terkait teknis pengelolaan dokumen arsip untuk mendukung bisnis perusahaan yang mapan. Dalam implementasinya pada tahun 2009 hingga 2015, USD menetapkan kebijakan pengelolaan dokumen berikut aturan turunannya, melengkapi sarana dan prasarana secara bertahap, membangun sumber daya manusia yang berkompeten dan professional dan penguatan kelembagaan. Hal tersebut dilakukan dalam rangka menjamin ketersediaan dokumen dan sekaligus peningkatkan kualitas pengelolaan dokumen perusahaan. Dalam kaitannya dengan kebijakan pengelolaan tersebut, PT Kereta Api Indonesia (Persero) mengacu pada UndangUndang Nomor 43 Tahun 2009 tentang Kearsipan berikut aturan turunannya seperti Peraturan Pemerintah yang terkait dan Peraturan Kepala Arsip Nasional Republik Indonesia (ANRI) sebagai pedoman penyelenggaraan kearsipan nasional. Berdasarkan undang-undang tersebut, penyelenggaraan kearsipan mencakup ruang lingkup keseluruhan penetapan kebijakan, pembinaan kearsipan, dan pengelolaan arsip dalam suatu sistem kearsipan nasional yang didukung oleh sumber daya manusia, prasarana dan sarana, serta sumber daya lainnnya. Seiring dengan kematangan unit USD dalam mengimbangi kompleksitas bisnis di perusahaan, pada tahun 2016 berhasil memperoleh Akreditasi A (sangat baik) dari ANRI. Pada saat yang bersamaan dilakukan juga migrasi dalam implementasi SMM ISO 9001:2008 menjadi ISO 9001: 2015.

Orientasi pada implementasi SMM ISO 9001:2015 adalah memperluas ruang lingkup dari yang sebelumnya pengelolaan dokumen menjadi penyelenggaraan dokumen. Berdasarkan penjelasan narasumber 1, pengelolaan dokumen merujuk pada tahapan pengelolaan dokumen aset berdasarkan siklus hidup. Adapun penyelenggaraan dokumen dimaksudkan sebagai pengelolaan dokumen dengan pendekatan manajemen (Plan-Do-Act-Check) (wawancara tanggal 19 Juli 2019 di USDA Kantor Pusat PT Kereta Api Indonesia). Perubahan ini mutlak diperlukan agar terjadi peningkatan kecukupan dan kepatuhan terhadap standarisasi yang sudah tersedia untuk tercapainya efektivitas dan efisiensi pengelolaan dengan memasukan unsur risiko (risk based thinking). Secara spesifik juga dikembangkan model pengelolaan dokumen era Hindia Belanda pada pengelolaan dokumen kepemilikan aset perusahaan yang dirumuskan dalam pengorganisasian dan SDM, preservasi, pelayanan dan monitoring dan audit. Sejak diterapkan dari 2015 ini model sudah mengalami dua kali perkembangan. Model yang pertama telah diperkenalkan pada lomba arsiparis teladan non PNS yang diselenggarakan ANRI yang disampaikan oleh Asman Land Ownership, Erna Purwatiningsih berhasil mendapatkan Juara I. Model selanjutnya semakin disempurnakan seiring dengan migrasi SMM ISO 9001:2015 dengan terpilih sebagai salah satu paper yang dipresentasikan (call for paper) pada International Seminar of Archives UGM 2017 oleh Manager Asset Ownership Document and Files, Ichwan. Model ini terus dikembangkan dan dianggap berhasil dengan tiga indikator sebagai berikut : (1) Tingkat (score) kepuasan pelanggan semakin baik dan dapat stabil "sangat puas" (konstan diatas 90\%), (2) 
Mendapatkan pengakuan dan penghargaan dari lembaga yang kompeten, (3) Mendapatkan komentar positif dari stakeholders.

\section{Model Pengelolaan Dokumen Kepemilikan Aset Berbasis ISO 9001: 2015 tentang Sistem Manajemen Mutu}

Dokumen kepemilikan aset dapat dikategorikan sebagai dokumen vital. Sebagaimana dijelaskan oleh (Franks, 2018) bahwa dokumen dikategorikan sebagai vital apabila “...essential for the continuation of an organization during and after an emergency as well as those that protect the legal and financial rights of the organization and individuals affected by its activities". Dalam perkembangannya, model pengelolaan dokumen vital, khususnya yang diimplementasikan di Indonesia, dinilai sudah tidak relevan dengan dinamika bisnis perusahaan. Oleh sebab itu, PT Kereta Api Indonesia (Persero) berpendapat perlunya perbaikan model pengelolaan dokumen yang kontekstual dan relevan. Adapun model pengelolaan dokumen kepemilikan aset yang diimplementasikan oleh Unit Assets Ownership Document and Files (USDA) Kantor Pusat PT Kereta Api Indonesia (Persero) dapat dicermati pada gambar 1.

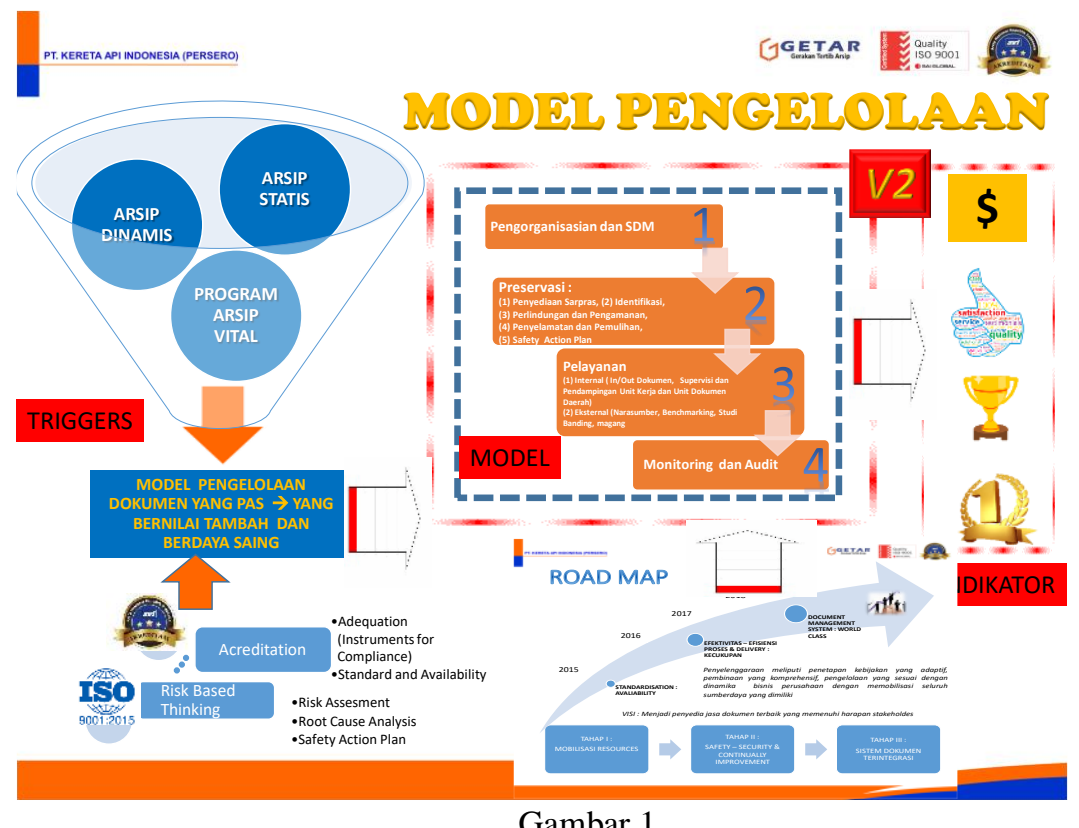

Model Pengelolaan Dokumen Kepemilikan Aset PT Kereta Api Indonesia (Persero)

Sumber: Ichwan

Adapun basis dalam mengimplementasikan pengelolaan dokumen kepemilikan aset adalah ISO 9001: 2015 tentang sistem manajemen mutu. Oleh sebab itu, tujuan akhir dari pengelolaan dokumen kepemilikan aset PT Kereta Api Indonesia (Persero) adalah terpenuhinya kebutuhan pelanggan dan stakeholders atas informasi yang terekam dalam dokumen kepemilikan aset sesuai persyaratan perundang-undangan maupun peraturan lainnya terkait dokumen maupun informasi. (Mulyadi, 2017) menyebutkan beberapa faktor yang melatarbelakangi perlunya dokumen kepemilikan aset dikelola dengan model tersebut, yaitu:

a. Usia fisik dokumen sudah tua, rapuh, namun unik karena proses penciptaannya pada kisaran abad 18 dan abad 19;

b. Tingkat kekerapan penggunaan dokumen yang cenderung tinggi;

c. Terdapat dokumen yang harus diolah;

d. Perlunya upaya digitalisasi, khususnya pada dokumen kepemilikan aset tanah;

e. Media dokumen yang bervariasi meliputi kertas biasa, kalkir, karton, dan kain kanvas; 
f. Memerlukan ruang simpan khusus;

g. Memerlukan perlakukan khusus dalam pengelolaannya.

Tahapan pengelolaan dokumen kepemilikan aset terdiri dari:

1. Pengorganisasian dan SDM, merujuk pada ISO 9001: 2015 tentang Sistem Manajemen Mutu, pengorganisasian dan SDM dikategorikan dalam ruang lingkup kepemimpinan, khususnya bagian peran organisasi, tanggung jawab, dan otoritas. Dalam konteks pengelolaan dokumen kepemilikan aset, aspek tersebut dimaknai sebagai pembagian tugas dan tanggung jawab untuk melaksanakan pengelolaan dokumen kepemilikan aset. Sumber Daya Manusia (SDM) dalam melaksanakan pengelolaan dokumen kepemilikan aset meliputi pejabat struktural (manajer dan asisten manajer) sebagai perencana, penyusun program, pengaturan, pengendali pelaksanaan kegiatan, koordinator monitoring dan evaluasi; serta staff sebagai pelaksana pengelolaan dokumen aset (Mulyadi, 2017). Staff sebagai pelaksana pengelolaan dokumen kepemilikan aset, secara umum belum memiliki latar belakang pendidikan kearsipan. Latar belakang pendidikan formal pelaksana tersebut antara lain: SMA, SMK Pertanian, SMK Grafika, S1 Manajemen, S1 Teknik Mesin, S1 Teknik Geodesi, dan D3 Kearsipan. Terkait SDM pengelola dalam ISO 9001: 2015, juga memperhatikan ruang lingkup dukungan, terutama bagian kompetensi. Dalam salah satu poinnya disebutkan bahwa “...the organization shall determine and provide the persons necessary for the effective implementation of its quality management system and for the operation and control of its processes". Narasumber 1 menguraikan lebih lanjut bahwa (wawancara tanggal 19 Juli 2019 di USDA Kantor Pusat PT Kereta Api Indonesia) untuk dapat menyelaraskan dengan persyaratan ISO tersebut, maka USDA PT Kereta Api Indonesia (Persero) juga memfasilitasi sumber daya manusia dengan pendidikan dan pelatihan, serta pendidikan lapangan secara bertahap dan berjenjang bagi seluruh pegawai, terutama terkait pengelolaan dokumen dan safety action plan.

2. Preservasi dokumen, merupakan prosedur melestarikan fisik dokumen (Bettington, 2008) yang meliputi:

a. Pemenuhan sarana simpan, seperti ruangan, gedung dan fasilitas pendukung lainnya. Hal ini diselaraskan dengan ruang lingkup dukungan pada ISO 9001: 2015, bagian infrastruktur, yang menyebutkan bahwa "...The organization shall determine, provide and maintain the infrastructure for the operation of its processes to achieve conformity of products and services";

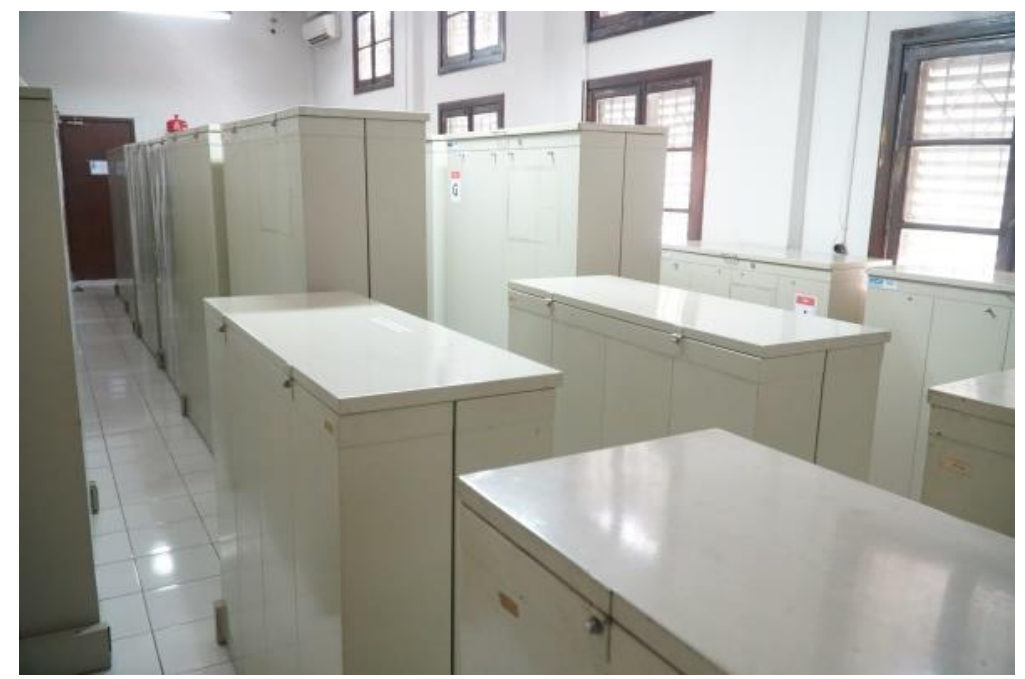

Gambar 2

Vertical Cabinet

Sumber: (Wahyuni, 2020) 
b. Mengidentifikasi dokumen, meliputi: seleksi, sortir, klasifikasi, penyusunan daftar dokumen kepemilikan aset;

c. Tahap perlindungan dan pengamanan dokumen dengan memperhatikan media dan kondisi ruang simpan;

d. Penyelamatan dan pemulihan dengan teknik restorasi dan enkapsulasi dokumen;

e. Program safety action plan.

3. Pelayanan dokumen, sebagai upaya meningkatkan pemanfaatan dokumen kepemilikan aset untuk kebutuhan pengembangan perusahaan (Megill, 2005), bukti hukum, dan pengambilan keputusan. Bentuk layanan dokumen kepemilikan aset terdiri dari:

a. Pelayanan internal, meliputi layanan penerimaan dokumen dari berbagai Daerah Operasi (DAOP) dan Divisi Regional (Divre), terutama di Pulau Jawa dan Sumatera; layanan permintaan salinan dokumen melalui persetujuan Vice President Corporate Document Management dan manajer USDA; layanan peminjaman dokumen asli melalui persetujuan direktur utama, Vice President Corporate Document Management dan manajer USDA dengan waku peminjaman 1 bulan dan dapat diperpanjang atas persetujuan Vice President Corporate Document Management; serta layanan supervise pendampingan pada unit kerja. Beberapa persetujuan tersebut dilakukan sebagai upaya implementasi ISO 9001: 2015 pada ruang lingkup operasi, yaitu "... When determining the requirements for the products and services to be offered to customers, the organization shall ensure that the requirements for the products and services are defined, including: any applicable statutory and regulatory requirements and those considered necessary by the organization. ...";

b. Pelayanan eksternal, antara lain magang mahasiswa, studi banding, narasumber.

4. Monitoring dan audit, merupakan aktivitas evaluasi yang berkesinambungan untuk memastikan pelaksanaan pengelolaan dokumen kepemilikan aset selaras dengan aturan dan pedoman yang digunakan sehingga dapat meraih tujuan yang telah ditetapkan. Tahapan ini merupakan implementasi dari ISO 9001: 2015 pada ruang lingkup performance evaluation. Beberapa aspek yang perlu diperhatikan saat evaluasi tersebut, berdasarkan ISO 9001: 2015, antara lain: “...what needs to be monitored and measured; the methods for monitoring, measurement, analysis and evaluation needed to ensure valid results; when the monitoring and measuring shall be performed; when the results from monitoring and measurement shall be analysed and evaluated..". Bentuk evaluasi kinerja yang diimplementasikan selain monitoring dan audit internal, adalah kepuasan pelanggan. Evaluasi tersebut dilakukan setelah pelaksanaan kegiatan layanan dokumen. Menurut narasumber 2 (wawancara tanggal 4 Februari 2020 di Kantor Pusat PT Kereta Api Indonesia Persero), monitoring yang dilaksanakan USDA yaitu pelaporan capaian kinerja setiap akhir pekan kerja, dan pelaporan capaian kinerja bulanan manajer untuk mengukur pelaksanaan kegiatan telah berjalan sesuai dengan target yang telah ditentukan. Adapun audit yang dilaksanakan di USDA terdiri dari audit internal dan eksternal. Audit internal implementasi ISO 9001: 2015 dilaksanakan minimal 1 tahun sekali oleh Unit Quality Assurance. Audit eksternal meliputi audit survilance yang dilaksanakan oleh SAI Global, dan audit pengawasan yang dilaksanakan Arsip Nasional Republik Indonesia (ANRI).

\section{Peran Pengelolaan Dokumen Kepemilikan Aset terhadap Keberhasilan Program Revitalisasi Jalur Kereta Api}

Berdasarkan Review Rencana Induk Perkeretaapian Nasional (Dirjenka-Departemen Perhubungan) yang diterbitkan pada tahun 2018, terdapat enam sasaran pengembangan jaringan dan layanan perkeretaapian yang ditargetkan tercapai pada 2030, yaitu: 
1. Jaringan perkeretaapian nasional mencapai $10.524 \mathrm{~km}$ (yang tersebar di Pulau Jawa dan Bali, Sumatera, Kalimantan, Sulawesi, dan Papua), termasuk jaringan kereta api kota atau perkotaan sepanjang $3.755 \mathrm{~km}$;

2. Sarana angkutan penumpang dengan jumlah lokomotif sebesar 2839 unit, kereta api antar kota 27.949 unit, dan perkotaan sejumlah 6.229 unit;

3. Sarana angkutan barang dengan jumlah lokomotif sebesar 2.475 unit dan gerbong 48.364 unit;

4. Peningkatan ekonomi wilayah tiap daerah;

5. Peningkatan konektivitas;

6. Penurunan angka kecelakaan transportasi darat.

Untuk dapat mencapai sasaran tersebut, khususnya di Pulau Jawa, pengembangan jaringan dan layanan perkeretaapian lebih dititikberatkan pada optimalisasi jaringan yang sudah ada. Salah satu kegiatan optimalisasi jaringan tersebut adalah reaktivasi atau revitalisasi jalur kereta api. Dalam kajiannya, (Purwoko, A.\&Haradongan, 2015) menjelaskan beberapa pertimbangan untuk mengaktifkan jalur kereta api yang tidak beroperasi, diantaranya: hemat energi, meminimalisasi tingkat polusi, mampu mengangkut secara massal, dan mengurangi beban angkutan jalan, baik untuk mengangkut penumpang maupun barang. Selain itu, secara aspek perekonomian regional, reaktivasi jalur kereta pun diharapkan mampu mempercepat gerak investasi bagi daerah-daerah yang dilalui jalur kereta tersebut (Dwiatmoko, 2019). Adapun permasalahan yang kemudian dihadapi terkait reaktivasi jalur kereta api adalah banyaknya jalur kereta api yang telah berubah penggunaanya (sebagian berubah fungsi menjadi perumahan, area bisnis, dll) dan prasarana jalur kereta api yang rusak. Oleh sebab itu, selain diperlukan koordinasi dengan melibatkan pemerintah daerah, swasta, maupun masyarakat sesuai peraturan yang berlaku, juga didukung dengan keberadaan dokumen.

Dokumen yang dimanfaatkan dalam upaya merevitalisasi jalur kereta api dikategorikan sebagai dokumen vital. Dalam perspektif kearsipan, merujuk pada Undang-Undang Nomor 43 Tahun 2009 tentang Kearsipan, dokumen vital adalah arsip yang keberadaannya merupakan persyaratan dasar bagi kelangsungan operasional pencipta arsip, tidak dapat diperbarui, dan tidak tergantikan apabila rusak atau hilang. Menurut (Franks, 2018), arsip vital dapat dikategorikan dalam dua jenis, yaitu arsip yang berkaitan dengan hak dasar warga negara dan informasinya berada dibawah kewenangan pemerintahan suatu negara, sebagai contoh akta kelahiran, buku nikah, surat kematian, dan sejenisnya; jenis kedua arsip yang berkaitan dengan keberlanjutan dan eksistensi suatu organisasi, memuat informasi yang merujuk pada perlindungan secara hukum dan finansial, baik organisasi maupun pihak-pihak terkait.

Oleh sebab itu, dalam pengelolaannya diperlukan upaya khusus agar dokumen vital tidak mudah rusak atau hilang. Pengelolaan dokumen kepemilikan aset tidak hanya dimaknai sebatas pada hal-hal teknis, namun juga memiliki cakupan yang lebih luas sehingga dapat pula dimaknai sebagai suatu kebijakan yang harus diimplementasikan. Menurut (Purwanto, E.A, dan Sulistyatuti, 2012), proses implementasi bermula sejak kebijakan ditetapkan atau memiliki payung hukum yang sah. Pasca penetapan kebijakan, tahapan implementasi dimulai dari membentuk organisasi, mengerahkan orang, sumberdaya, teknologi, menetapkan prosedur, dan seterusnya dengan tujuan agar kebijakan yang telah ditetapkan dapat diwujudkan. (Purwanto, E.A, dan Sulistyatuti, 2012) menegaskan bahwa dampak kebijakan yang paling nyata adalah perubahan kondisi yang dirasakan oleh kelompok sasaran, yaitu dari kondisi yang satu ke kondisi lain yang lebih baik.

Tahapan implementasi model pengelolaan dokumen kepemilikan aset dimulai saat pembentukan unit USD pada 2009. USD, sebagai unit yang baru saja dibentuk, dihadapkan pada suatu tantangan besar yaitu menyelesaikan backlog pengelolaan dokumen perusahaan khususnya dokumen kepemilikan aset dan partisipasi nyata yang sesegera mungkin terlibat dalam 
transformasi bisnis yang sedang dilaksanakan perusahaan. Pada waktu itu manajemen melihat bahwa salah satu problem terbesar yang menghambat bisnis karena buruknya pengelolaan dokumen khususnya dokumen kepemilikan aset. Banyak aset digunakan/diduduki pihak diluar perusahaan tidak sesuai ketentuan perusahaan sangat membelenggu bisnis. Menurut narasumber 1 (wawancara tanggal 19 Juli 2019 di USDA Kantor Pusat PT Kereta Api Indonesia), dengan kondisi tersebut disusunlah roadmap unit agar langkah yang diambil bisa cepat, tepat dan terukur untuk segera berperan seperti yang diharapkan perusahaan.

Tahap I road map memobilisasi semua sumberdaya yang dimiliki dengan cara melakukan standarisasi untuk menjamin ketersediaan dokumen untuk dilayankan. Pada awalnya kinerja unit secara gradual mengalami peningkatan yang cukup signifikan dalam pelayanan dokumen. Akan tetapi peningkatan yang telah dicapai dirasa belum bisa konsisten karena beberapa faktor seperti ketergantungan kepada beberapa staf tertentu, cara pandang berbeda dalam kerjasama tim dan vakum dalam improvement. Penulis sebagai salah satu Manager baru di unit USD menginisiasi penyusunan ulang bisnis proses dalam pelayanan dokumen melalui penyusunan SOP dan IK dan sesegera mungkin mengadopsi suatu sistem kerja yang sudah terbukti membawa konsistensi dan improvement dalam pelayanan. Selanjutnya secara mudah unit berhasil mendapatkan sertifikat ISO 9001:2008 karena banyak prasyarat telah pararel dibuat sebelumnya.

Implementasi ISO 9001:2008 dengan ruang pengelolaan dokumen kontrak dan dokumen legal lainnya, dokumen kepemilikan aset dan korespondensi. Seiring dengan perjalanan waktu, kematangan unit, kompleksitas pelayanan dokumen dan perkembangan ISO 9001, pada tahun 2016, implementasinya mengalami migrasi menjadi ISO 9001:2015 dengan ruang lingkup yang lebih luas yaitu penyelenggaraan dokumen perusahaan yang meliputi pembuatan kebijakan, pengembangan (manajemen) dokumen, pengelolaan korespondensi-pengarsipan dokumen umum dokumen elektronik dan telegraf, manajemen dokumen kepemilikan aset dan manjemen dokumen legal serta pusat arsip.

Adapun pelatihan yang dilaksanakan sebagai dasar dalam membangun kompetensi staf dilakukan dengan cara pendidikan latihan (diklat) dan pendidikan lapangan (diklap). Diklat terdiri dari internal yang dilakukan oleh perusahaan melalui unit Traning and Education berupa diklat dasar administrasi perkantoran dan diklat eksternal dengan mengikuti diklat/bimtek/seminar yang dilakukan oleh Pusdiklat ANRI maupun lainnya. Demikian juga dilakukan internal yaitu dilakukan sendiri sebagai bentuk penambahan kompetensi secara tematis maupun refreshing kompetensi.

Untuk memastikan terpenuhinya keys performance indicator (KPI) pada setiap kegiatan dilaksanakan monitoring secara berkala. Monitoring dilaksanakan secara berkala setiap pekan yang terdiri dari laporan kinerja setiap akhir pekan secara tertulis berjenjang berikut reviewnya yang dilaksanakan oleh Asman secara bergilir mewakili Manager. Selain itu untuk memastikan review berjalan baik juga dilaksanakan briefing untuk membuka komunikasi langsung dan mengharmoniskan kerjasama tim dengan melibatkan seluruh staf yang dipimpin. Manager membahas tentang catatan pencapaian dan penyelesaian permasalahan (jika ada), informasi, penambahan wawasan/refreshing pengetahuan dari manager dan penyampaian usulan/aspirasi improvement. Melengkapi monitoring juga dilakukan evaluasi kinerja dalam periode bulanan, triwulanan, semesteran dan tahunan.

Hal lain terkait dengan usaha pemenuhan KPI juga dilaksanakan melalui audit baik internal maupun eksternal terkait aspek keuangan, surveillance/pengawasan atas diraihnya Sertifikasi ISO 9001 dan Akreditasi A Kearsipan. Audit internal dilaksanakan oleh unit di dalam perusahaan yaitu unit Internal Auditor (SPI) secara random dan audit implementasi ISO 9001 oleh unit Quality Assurance (USQ) setiap setahun sekali. Sedangkan audit eksternal dilaksanakan oleh badan/organisasi di luar perusahaan untuk memastikan implementasi ISO 9001 berjalan dengan 
baik oleh lembaga yang menerbitkan sertifikasi ISO 9001 (SAI Global) dalam bentuk audit surveillace setiap tahun dan audit resertifikasi setiap tiga tahun dan audit pengawasan atas akreditasi kearsipan oleh ANRI yang direncanakan setahun sekali.

Penyempurnaan pengelolaan dokumen khususnya preservasi juga dilaksanakan dengan melibatkan pihak eksternal dalam bentuk hubungan antar lembaga yang saling menguntungkan, baik yang diikat dengan nota kesepahaman (MoU) ataupun tidak pada beberapa bidang, diantaranya: pengolahan dokumen (LAPAN, ANRI, NAN), preservasi/konservasi (Dinas Arsip Yogyakarta, Kraton Ngayogyakarto Hadiningrat, Museum Sono Budoyo, ANRI, NAN, Arsip Bank Mandiri, Arsip Bank Indonesia, Arsip UGM), penelusuran dokumen (ANRI, NAN), archival science (UGM, UI, ANRI, NAN). Unit USD mendapat banyak kesempatan untuk belajar dalam bentuk benchmarking, undangan pelatihan maupun magang dari institusi tersebut.

Berapa rencana yang akan dilakukan dalam rangka menuju Tahap III (2020 - ...): Document Integration System, untuk mencapai penyelenggaraan dokumen berkelas dunia (world class document management), Unit USD berencana untuk melengkapi standar pengelolaan dokumen dengan mengimplementasikan Sistem Rekod Manajemen ISO 30300 series dengan terlebih dulu mengadopsi standar Manajemen Rekod ISO 15489:2016 dan juga standar lain yang terkait manajemen dokumen secara bertahap. Hal ini dimaksudkan agar sustainabilitas penyelenggaraan dokumen semakin baik agar bisa membawa nilai tambah dan daya saing bagi bisnis perusahaan.

Salah satu contoh peran pengelolaan dokumen kepemilikan aset berbasis ISO 9001:2015 dokumen jalur kereta api terhadap keberhasilan program revitalisasi jalur kereta api yang saat ini ada adalah reaktivasi jalur kereta api legendaris Cibatu - Garut - Cikajang yang dimulai tahun 2019. Jalur Garut-Cikajang yang dibangun 1930 akhirnya ditutup pada September 1982 sedangkan jalur Cibatu - Garut yang dibangun 1889 akhirnya ditutup menyusul pada Desember 1983. Sekilas informasi bahwa Garut pada zaman Hindia Belanda mempunyai julukan Swiss van Java karena memiliki panorama yang sangat indah dan menjadi salah satu tempat peristirahatan terbaik di zamannya sehingga banyak tokoh penting mengunjunginya seperti D. Fock, Gubernur Jenderal Hindia Belanda, George Clemenceu, Perdana Menteri Prancis, Louis Couperus, novelis dan penyair Belanda, Pangeran Leopold III, bangsawan Belgia, Putri Astrid, bangsawan Swedia, Renate Muller dan hans Albers, artis Jerman dan Charlie Chaplin, sutradara dan artis film bisu Inggris, sampai dua kali mengunjungi Garut, dan lain-lain.

Di Jawa Barat selain reaktivasi jalur Cibatu - Garut (19,4 km) - Cikajang (47,5km), rencananya juga akan dilakukan pada jalur Rancaekek - Tanjungsari (11,5 km, aktif periode 1921 - 1978), jalur Banjar - Pangandaran - Cijulang (82 km, aktif periode 1916 - 1982) jalur Bandung - Ciwidey (37,8 km, aktif periode 1921 - 1982). Pada saat tulisan ini disusun reaktivasi untuk tahap pertama reaktivasi jalur Cibatu - Garut sepanjang 19,4 km dengan jalur tunggal (single track) sudah sampai pada tahap finalisasi pekerjaan dan pengujian sertifikasi prasarana jalan rel, jembatan, persinyalan dan fasilitas lainnya dan beroperasi pada Februari 2020.

Untuk mendukung upaya tersebut tercatat dalam periode 2018 - 2019, 17 unit di PT. Kereta Api Indonesia (Persero) yang terkait dengan kegiatan langsung maupun tak langsung reaktivasi membutuhkan pelayanan dokumen yang terdiri dari kepemilikan tanah, jalan rel dan jembatan telah dilayani oleh unit USDA dengan lebih dari 750 dokumen. Dokumen yang rata-rata diatas 90 tahun tersebut dilayankan dalam bentuk softcopy maupun hardcopy. Unit-unit yang berhasil dilayani tersebut kemudian diukur tingkat kepuasannya dan diperoleh nilai lebih dari $91 \%$ atau sangat puas (4 skala pengukuran). 


\section{SIMPULAN}

Dokumen merupakan aset vital bagi suatu organisasi, tak terkecuali PT Kereta Api Indonesia (Persero) sebab mengandung informasi terkait kerja vital menyediakan sarana transportasi yang handal bagi masyarakat Indonesia. Informasi yang terkandung dalam dokumen arsip tersebut haruslah dapat didayagunakan. Semakin baik suatu organisasi dalam mendayagunakan informasi yang dikelola, maka informasi tersebut akan semakin bernilai guna. Dokumen kepemilikan aset memiliki standarisasi pengelolaan yang berbeda dengan jenis aset lainnya. Oleh sebab itu, PT Kereta Api Indonesia (Persero) menggunakan pendekatan manajerial berbasis ISO dalam upaya pengelolaan dokumen kepemilikan asetnya. Dalam timeline yang telah dirancang dan tengah diimplementasikan, PT Kereta Api Indonesia (Persero) menggunakan ISO 9001 sebagai dasar pijakan. Dalam perkembangan selanjutnya, PT Kereta Api Indonesia (Persero), secara bertahap, mengadopsi standar ISO 15489:2016 terkait Records and Information Management menuju ISO 30300.

Model pengelolaan dokumen kepemilikan aset, khususnya di Unit Asset Ownership Document and Files, berupaya mengintegrasikan pengelolaan arsip dinamis, arsip statis, dan arsip vital. Kegiatan pelestarian dokumen menjadi bagian tak terpisahkan dalam model pengelolaan tersebut. Model pelestarian dokumen kepemilikan aset terdiri dari: penyediaan sarana dan prasarana, identifikasi, perlindungan dan pengamanan, penyelamatan dan pemulihan, serta safety action plan. Untuk dapat menjamin kegiatan pengelolaan dokumen kepemilikan aset berjalan sesuai dengan standard, dilakukan monitoring dan audit sebagai upaya mengevaluasi pengelolaan arsip yang tengah berjalan. Pada dasarnya, model pengelolaan tersebut menitik-beratkan pada upaya pelestarian informasi dengan konsep yang mendekati pada model records continuum. Untuk dapat menyimpulkan bahwa model pengelolaan dokumen arsip di PT Kereta Api Indonesia (Persero) telah menganut model records continuum, masih perlu dilakukan pengkajian lebih dalam dan komprehensif. Meski demikian, terkait dengan pelestarian dokumen arsip, model yang tengah diimplementasikan hingga saat ini oleh PT Kereta Api Indonesia (Persero) dinilai telah mampu menunjang keberhasilan program revitalisasi jalur kereta api di Indonesia. Hal ini dapat dibuktikan dengan semakin banyaknya jalur kereta api yang direaktivasi dengan tujuan membuka meningkatkan pertumbuhan ekonomi kawasan sepanjang jalur kereta api yang direaktivasi melalui terbukanya aksesibilitas, berkembangnya industri dan pariwisata.

\section{DAFTAR PUSTAKA}

Arsip Nasional Republik Indonesia. (2009). Undang-Undang Nomor 43 Tahun 2009 tentang Kearsipan. Jakarta: Arsip Nasional Republik Indonesia.

Bettington, J. (n.d.). Keeping Archives. Australian Society of Archivists Inc. Diunduh dari https://www.archivists.org.au/learning-publications/keeping-archives-3rd-ed

Cognoscenti Consulting Group. (2015). Standar Internasional ISO 9001: 2015 tentang Sistem Manajemen Mutu - Persyaratan. Diunduh dari http://qms.pom.go.id/sites/default/files/4.\%20Standard\%20ISO\%209001_2015\%202\%20ba hasa.pdf

Dwiatmoko, H. (2019). Peran Infrastruktur Perkeretaapian Bagi Pertumbuhan Ekonomi Wilayah. Jurnal Manajemen Aset Infrastruktur\&Fasilitas, 3(2), 89-98.

Elmawati \& Ismiyati. (2017). Preservasi Arsip Vital (Studi Kasus di Biro Umum, Hukum, dan Kepegawaian Universitas Negeri Semarang). Economic Education Analysis Journal, 6(3), 912-922. 
Franks, P. C. (2018). Records and Information Management 2nd Edition. American Library Association.

Hayati, N.\&Noviani, G. . (2019). Pengelolaan dan Jaminan Keamanan Arsip Vital Kantor Notaris. Al Maktabah: Jurnal Komunikasi Dan Informasi Perpustakaan, 18(1), 22-36.

Megill, K. . (2005). Corporate Memory: Records and Information Management in the Knowledge Age. Munchen: K.G.Saur. Diunduh dari https://library.oapen.org/bitstream/handle/20.500.12657/31666/626355.pdf?sequence $=1$

Moleong, L. J. (2014). Metodologi Penelitian Kualitatif Edisi Revisi. Bandung: Rosda Karya.

Mulyadi, I. (2017). Pengelolaan Dokumen Transportasi Kereta Api 1864-1942 dan Layanan di Unit Corporate Document Management PT Kereta Api Indonesia. Prosiding Internasional Kearsipan, 125.

Novanti, D, \&Hermintoyo, M. (2019). Pengelolaan Arsip Vital Sertifikat Tanah Dengan Model Kontinum Dokumen Di Kantor Pertanahan Kota Semarang. Jurnal Ilmu Perpustakaan, 6(3), 1-10.

Nurtanzila, L. (2018). Penerapan Disaster Recovery and Contingency Planning Pada Perlindungan Arsip Vital di BPN DIY. Diplomatika: Jurnal Kearsipan Terapan, 1(2), 82-92. https://doi.org/https://doi.org/10.22146/diplomatika.32123

Pamungkas, D.A\&Kurniawan, A. . (2019). Pengaruh Pengelolaan Arsip Vital Terhadap Pemenuhan Kebutuhan Informasi Pegawai PT Pelindo III Cabang Tanjung Emas Semarang. Jurnal Ilmu Perpustakaan, 6(3), 51-60.

Purwanto, E.A, dan Sulistyatuti, D. . (2012). Implementasi Kebijakan Publik: Konsep dan Aplikasinya di Indonesia. Yogyakarta: Gava Media.

Purwoko, A.\&Haradongan, F. (2015). eaktivasi Jalur Kereta Api Lintas RangkasbitungPandeglang-Labuan. Jurnal Penelitian Transportasi Darat, 17(3), 171-182.

Qowam, P.A\&Permata, R. . (2019). Upaya Penyelamatan Informasi Arsip Vital Melalui Digitalisasi Arsip Register Akta Kelahiran di Dinas Kependudukan dan Pencatatan Sipil Kabupaten Boyolali. Jurnal Ilmu Perpustakaan, 6(3), 171-180.

Raap, O. J. (n.d.). Sepoer Oeap di Jawa Tempo Doeloe. Jakarta: Kompas Gramedia.

Vannia, A. M. \&Alamsya. (2019). Penilaian Resiko Arsip Vital Oleh Jasa Aldas (Adaro Land Documentation and Archiving Services) Dan Petugas Kearsipan Di PT. Adaro Persada Mandiri: Studi Komparasi. Jurnal Ilmu Perpustakaan, 8(3), 108-117.

Wahyuni, E. R. . (2020). Prosedur Monitoring dan Audit Internal di Unit Assets Ownership Document and Files (USDA) Oleh Unit Quality Assurance Kantor Pusat PT Kereta Api Indonesia (Persero). 